\title{
An Integral Approach Toward Transcending the Pedagogical Matrix: A Sociology Instructor's Personal Reflection
}

\author{
Michael Ortiz
}

This article, in some respects, acts as a sequel to my previous article titled "Race, Class, and Gender in the Pedagogical Matrix." Here, I continue to assess and discuss educational and pedagogical environments as spaces through which neoliberal institutional arrangements and ideologies dominate the setting. Particularly, I discuss how these pedagogies work to severely constrain students' self-awareness and creative possibilities; and I expose the neoliberal context as a dominant system that operates under the false guise of implied universal separateness. (I do so predominantly by utilizing the deeper contexts of quantum mechanics and neuroscience.) In response however, I cite alternative, integral approaches to education that offer a significantly different way for students to learn about themselves and their social environment; whereby self-definition and self-empowerment are emphasized. Specifically though, I preface this article by divesting how my own pedagogical and personal evolution has led me to develop my own effective, integral practices; which I share as an example for all others within higher education to read about in the hopes that they become inspired to potentially develop their own integral pedagogical methods for their specific social or academic environments. [Article copies available for a fee from The Transformative Studies Institute. E-mail address: journal@transformativestudies.org Website: http://www.transformativestudies.org (C2015 by The Transformative Studies Institute. All rights reserved.]

KEYWORDS: Pedagogy, Education, Integral, Sociology, Teaching, Empowerment.

\footnotetext{
${ }^{1}$ Michael Ortiz is an adjunct lecturer of sociology at CUNY Kingsborough Community College in Brooklyn, NY. His interests lie in developing and utilizing integral approaches that can be applied inside and outside of the classroom with the intent of expanding consciousness, cultivating empowerment, and activating social change. Address correspondence to: Michael Ortiz, CUNY Kingsborough Community College, 303 Bay 10 Street, Brooklyn, New York 11228; e-mail: Michael.Ortiz@kbcc.cuny.edu.
} 